\title{
Isotype distribution of anticardiolipin antibodies in systemic lupus erythematosus: prospective analysis of a series of 100 patients
}

Ricard Cervera, Josep Font, Alfons López-Soto, Francesc Casals, Lucio Pallarés, Albert Bové, Miguel Ingelmo, Alvaro Urbano-Márquez

\begin{abstract}
A prospective study of IgG and IgM isotypes of anticardiolipin antibodies $(\mathrm{aCL})$ in a series of 100 patients with systemic lupus erythematosus was carried out. To determine the normal range of both isotype titres a group of 100 normal control serum samples was studied and a log-normal distribution of IgG and IgM isotypes was found. The IgG anticardiolipin antibody serum was regarded as positive if a binding index greater than 2.85 (SD 3.77) was detected and a binding index greater than 4.07 (3.90) was defined as positive for IgM anticardiolipin antibody. Twenty four patients were positive for IgG $\mathrm{aCL}, 20$ for IgM $\mathrm{aCL}$, and 36 for IgG or IgM aCL, or both. IgG aCL were found to have a significant association with thrombosis and thrombocytopenia, and IgM aCL with haemolytic anaemia and neutropenia. Specificity and predictive value for these clinical manifestations increased at moderate and high anticardiolipin antibody titres. In addition, a significant association was found between aCL and the presence of lupus anticoagulant. Identification of these differences in the anticardiolipin antibody isotype associations may improve the clinical usefulness of these tests, and this study confirms the good specificity and predictive value of the anticardiolipin antibody titre for these clinical manifestations.
\end{abstract}

Several recent studies found that patients with antiphospholipid antibodies ( $\mathrm{aPL}$ ) are prone to repeated episodes of venous or arterial thrombosis, or both, ${ }^{1-11}$ recurrent fetal loss, ${ }^{6-8} 11-15$ and thrombocytopenia. ${ }^{2-689} 111516$ In addition, there have been reports of the possible association of aPL with haemolytic anaemia ${ }^{17}$ and neurological events such as cerebrovascular accidents, ${ }^{18}$ seizures, migraine, ${ }^{19}$ and chorea. ${ }^{20}$ Other authors, however, consider that no association exists and aPL are only an epiphenomenon. ${ }^{21-23}$ In fact, few prospective studies of a large number of unselected patients have been carried out and no definitive conclusions have been reached.

Of the various aPL, anticardiolipin antibodies (aCL) have received more attention owing to their sensitive, reproducible, and reliable detection by radioimmunoassay ${ }^{3}$ or enzyme linked immunosorbent assay (ELISA). ${ }^{24}$ Several studies suggest that aCL are closely related to the lupus anticoagulant and the biological false positive standard tests for syphilis (BFP-STS). ${ }^{6}$ Although these antibodies are not restricted to patients with systemic lupus erythematosus (SLE), they are often found in these patients.

Our main objectives were to determine the prevalence of $\operatorname{IgG}$ and $\operatorname{IgM}$ anticardiolipin antibody isotypes in 100 consecutive patients with SLE in order to compare their possible association with clinical and laboratory manifestations and disease activity.

\section{Patients and methods}

\section{PATIENTS}

Clinical laboratory features of 100 consecutive and unselected patients ( 93 female, seven male) with SLE were prospectively studied during the years 1986-1987. All fulfilled four or more of the 1982 American Rheumatism Association (ARA) criteria for the classification of SLE. ${ }^{25}$

\section{DISEASE ACTIVITY AND SUBSETS}

Individual SLE clinical features were considered if they fulfilled the definitions of the ARA glossary. ${ }^{26}$

To assess disease activity all records were evaluated without knowledge of the anticardiolipin antibody status. Disease was judged to be clinically active when the following signs or symptoms were present: typical dermatitis; arthritis; serositis; central nervous system abnormalities (recent onset of chorea, seizures, psychosis, organic brain syndrome in the absence of offending drugs or known metabolic derangements, embolic cerebrovascular accidents); thrombocytopenia $\left(<100 \times 10^{9} / 1\right)$; haemolytic anaemia; vasculitis (biopsy); or nephritis (recent onset of haematuria ( $>10$ red blood cells/high power field) or casts, or proteinuria $>500 \mathrm{mg} /$ $24 \mathrm{~h}$, or a $25 \%$ increase in serum creatinine). Sixty patients were classified as 'active' and $\mathbf{4 0}$ as 'inactive' based on these criteria.

Venous or arterial thrombosis, or both, was diagnosed in 10 patients. Diagnosis of venous thrombosis (seven patients) was based on clinical presentation and confirmed by venogram. Two patients with clinical features of cerebrovascular accidents or transient ischaemic attacks and evidence of cerebral infarction on computed tomographic scans, and two patients with clinical, electrocardiogram, and laboratory evidence of myocardial infarction were defined as having arterial thrombosis. None of the 93 women had a fetal loss during the study. Thrombocytopenia was present in 16 patients (platelet count $<100 \times 10^{9} / 1$ on two occasions at least two weeks apart). Nine patients were considered to have haemolytic anaemia because they had a fall of at least $30 \mathrm{~g} / \mathrm{l}$ in their blood haemoglobin, coinci- 
dent with a rise in unconjugated bilirubin of at least $10.3 \mu \mathrm{mol} / \mathrm{l}$ and a reticulocyte count above $5 \%$ at the time of the haemolytic episode. A positive Coombs' test was not considered essential, though most patients were tested. Neutropenia was present in five patients (neutrophil count lower than $0.5 \times 10^{9} / 1$ on two occasions at least two weeks apart). Serum samples for the detection of anticardiolipin antibody were collected during the clinical events.

\section{CONTROLS}

The normal control group consisted of 100 healthy blood donors from the blood bank of the hospital clinic matched for age and sex. All showed normal coagulation assays and negative serological test for syphilis.

\section{ANTICARDIOLIPIN ANTIBODY ELISA}

Anticardiolipin antibodies were measured by an ELISA as described by Loizou et $a l^{24}$ and Gharavi $e t a l^{27}$ with minor modifications of our own. Briefly, the flat bottomed wells of microtitre plates (Nunc, Denmark) were coated with $30 \mu \mathrm{l} /$ well of cardiolipin (Sigma) suspended in ethanol at a concentration of $50 \mu \mathrm{g} / \mathrm{ml}$ and left to dry overnight at $4^{\circ} \mathrm{C}$. The plates were treated for non-specific binding by incubation with 110 $\mu \mathrm{l}$ of $10 \%$ fetal calf serum (FCS; Flow) in phosphate buffered saline (PBS, $\mathrm{pH} 7 \cdot 2$ ) solution for two hours. The wells were then washed four times with $120 \mu \mathrm{l}$ of PBS, and $100 \mu \mathrm{l}$ of a 1:100 dilution of the serum in PBS-FCS solution was added to triplicate test wells; similarly, $100 \mu \mathrm{l}$ of PBS-FCS was added to the blank control wells. The plates were incubated for one hour at room temperature. After washing the plates with PBS $100 \mu \mathrm{l}$ of a goat antihuman IgG or IgM (Tago Inc) diluted 1:4000 was added to each well and incubated for one hour at $37^{\circ} \mathrm{C}$. The plates were washed again with PBS, and $100 \mu$ l of alkaline phosphatase conjugated antibody (rabbit antigoat IgG; Sigma) diluted 1:1000 in PBS-FCS was added to each well. The plates were then placed in a humidifier incubator at $25^{\circ} \mathrm{C}$ for one hour. They were washed with diethanolamine buffer (pH 9.8), and $100 \mu \mathrm{l} p$-nitrophenyl phosphate $(1 \mathrm{mg} / \mathrm{ml})$ prepared in diethanolamine immediately before use was added to each well. The plates were incubated in the dark at room temperature for one hour. The reaction was stopped by addition of $3 \mathrm{M} \mathrm{NaOH}(50 \mu \mathrm{l})$ to all wells and the optical absorbance was read at 405 $\mathrm{nm}$ on an ELISA microplate reader (Organon). Results were expressed as binding index (BI) calculated from optical absorbance (OA) values as follows:

$$
\mathrm{BI}=\frac{\mathrm{OA}(\text { test samples) }-\mathrm{OA}(\text { blank })}{\mathrm{OA}(\text { referred normal pool) }-\mathrm{OA}(\text { blank })}
$$

\section{COAGULATION ASSAYS}

The following tests were carried out in all patients to detect the lupus anticoagulant according to the methods previously reported: prothrombin time, activated partial thromboplastin time, kaolin clotting time, diluted Russell's viper venom time, and tissue thromboplastin inhibition test. ${ }^{28}{ }^{29}$ The reagents used were rabbit brain thromboplastin for prothrombin time and tissue thromboplastin inhibition test, bovine thromboplastin for diluted Russell's viper venom time, and platelet factor 3 plus activator from rabbit brain tissue for activated partial thromboplastin time. The positive value for every coagulative test was defined as $3+$ standard deviations above the mean normal value of the control group. To rule out a deficit in a coagulation factor each assay was performed also with a mixture of patient and control plasma $(1 / 1, \mathrm{vol} / \mathrm{vol})$. Patients were considered to have lupus anticoagulant when at least two assays were positive.

SEROLOGICAL TEST FOR SYPHILIS

A macroscopic rapid plasma reagin (Knickerbocker) was used in an $18 \mathrm{~mm}$ circle card test.

\section{OTHER LABORATORY STUDIES}

Antinuclear antibodies were determined by indirect immunofluorescence with mouse liver as substrate. Anti-double-stranded DNA antibodies were determined by Farr's ammonium sulphate precipitation technique. ${ }^{30}$ Complement components $(\mathrm{C} 3, \mathrm{C} 4)$ were estimated by radial immunodiffusion and $\mathrm{CH}_{50}$ by Lachmann and Hobart's haemolytic technique. ${ }^{31}$

\section{STATISTICAL ANALYSIS}

Conventional $\chi^{2}$ analysis and Fisher's exact test were used to determine the statistical significance of clinical and laboratory findings. Stepwise regression analysis was used to correlate anticardiolipin antibody positivity with 16 variables (sex, age, SLE activity, cutaneous involvement, arthritis, serositis, central nervous system disease, renal involvement, venous or arterial thrombosis, or both, thrombocytopenia, haemolytic anaemia, neutropenia, lymphopenia, antinuclear antibodies, anti-DNA antibodies, and complement components) in all patients.

The sensitivity, specificity, and predictive value of aCL at low, moderate, or high titres for venous or arterial thrombosis, or both, thrombocytopenia, haemolytic anaemia, and neutropenia were determined according to the method of Galen and Gambino. ${ }^{32}$

\section{Results}

\section{ANTICARDIOLIPIN ANTIBODY ISOTYPE}

DISTRIBUTION

Study of 100 normal control serum samples showed a log-normal distribution of both IgG and $\operatorname{IgM}$ anticardiolipin antibody titres (figs 1 and 2). Values were considered normal when the logarithms of the binding indexes were below the 98 centile of cumulative normal distribution. The IgG aCL were regarded as positive if a binding index greater than 2.85 (SD 3.77) was obtained. A binding index greater than $4.07(3.90)$ was defined as positive for $\operatorname{IgM}$ aCL. When these conventions were used 36 patients were positive for IgG or IgM aCL, or 


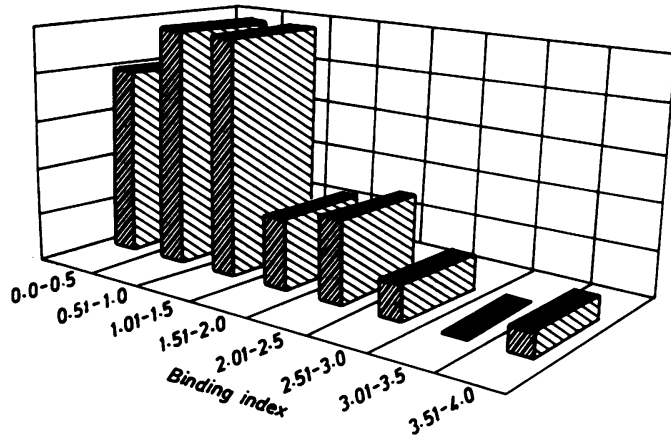

Figure 1: IgG anticardiolipin antibody distribution in normal control serum samples.

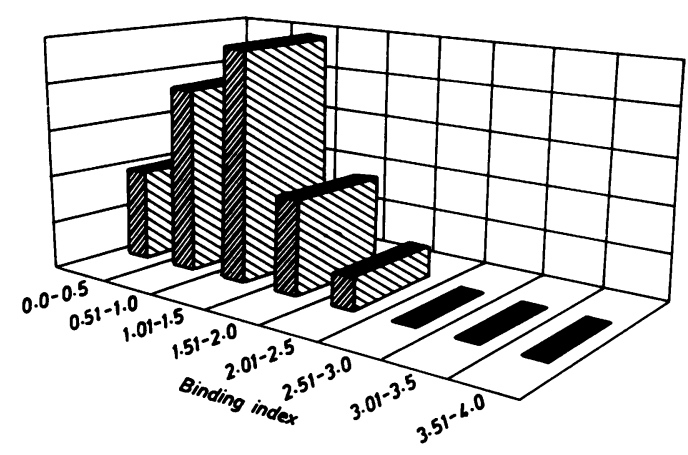

Figure 2: IgM anticardiolipin antibody distribution in normal control serum samples.

both. The isotype spectra were as follows: 24 patients were positive for IgG aCL and 20 for IgM aCL. All were arbitrarily divided into three subgroups consisting of low, moderate, or high titres of aCL. Only eight patients had both IgG and IgM aCL (table 1). None of the control sera was positive for IgG or IgM aCL.

Statistically significant association was found between the presence of aCL and lupus anticoagulant ( $p=0.01$ ), but not between $\mathrm{aCL}$ and BFP-STS (rapid plasma reagin).

\section{IgG ANTICARDIOLIPIN ANTIBODY}

When compared with the 76 patients without IgG aCL the patients with IgG aCL were found to have an increased incidence of thrombosis $(p=0.001)$, thrombocytopenia $(p=0.03)$, and SLE activity $(p=0.005)$. Stepwise regression analysis of IgG anticardiolipin antibody titres with the 16 variables previously described showed significant correlations with thrombosis $(p=0.001)$ and thrombocytopenia $(p=0.03)$, but not with SLE activity.

Table 2 shows the sensitivity, specificity, and predictive value of the IgG anticardiolipin antibody test at low, moderate, and high anticardiolipin antibody titres for thrombosis and thrombocytopenia. At low titre the specificity of the IgG anticardiolipin antibody test for thrombosis and thrombocytopenia was greater than $80 \%$, the sensitivity for thrombosis was $70 \%$ and for thrombocytopenia $47 \%$, but the predictive values were quite low. At moderate and high titres, however, the specificity of the test for both thrombosis and thrombocytopenia varied from $89 \%$ to $96 \%$ and its predictive value was in
Table 1: Isotype spectra of anticardiolipin antibody positive patients

\begin{tabular}{|c|c|c|}
\hline Patient No & $I g G a C L^{*}$ & $I g M a C L$ \\
\hline 1 & + & - \\
\hline $\begin{array}{l}2 \\
3\end{array}$ & $\begin{array}{l}+ \\
++\end{array}$ & $\stackrel{++}{-+}$ \\
\hline 4 & + & - \\
\hline 5 & +++ & +++ \\
\hline $\begin{array}{l}6 \\
7\end{array}$ & - & $\begin{array}{l}+++ \\
++\end{array}$ \\
\hline 8 & $\overline{t+}$ & $\stackrel{+++}{-+}$ \\
\hline 9 & ++ & $\overline{++}$ \\
\hline 10 & + & - \\
\hline 11 & ++ & - \\
\hline 12 & - & +++ \\
\hline $\begin{array}{l}13 \\
14\end{array}$ & $\stackrel{+}{-}$ & $\begin{array}{l}+ \\
+++\end{array}$ \\
\hline $\begin{array}{l}14 \\
15\end{array}$ & - & + \\
\hline 16 & + & - \\
\hline 17 & - & +++ \\
\hline $\begin{array}{l}18 \\
19\end{array}$ & $\stackrel{++}{+}$ & $\overline{+}++$ \\
\hline 20 & +++ & + \\
\hline $\begin{array}{l}21 \\
22\end{array}$ & $\stackrel{++}{+}$ & $\overline{+}$ \\
\hline 23 & - & + \\
\hline 24 & - & ++ \\
\hline $\begin{array}{l}25 \\
26\end{array}$ & \pm & $\overline{+}++$ \\
\hline $\begin{array}{l}20 \\
27\end{array}$ & $\bar{t}$ & $\begin{array}{l}+++ \\
+++\end{array}$ \\
\hline 28 & ++ & \\
\hline $\begin{array}{l}29 \\
30\end{array}$ & $\begin{array}{l}+++ \\
+\end{array}$ & ${ }_{-}^{+++}$ \\
\hline 31 & ++ & - \\
\hline 32 & +++ & - \\
\hline $\begin{array}{l}33 \\
34\end{array}$ & $\begin{array}{l}++ \\
++\end{array}$ & $=$ \\
\hline $\begin{array}{l}34 \\
35\end{array}$ & + & - \\
\hline 36 & - & +++ \\
\hline
\end{tabular}

${ }^{*} \mathrm{aCL}=$ anticardiolipin antibodies.

$+=$ low titre (IgG: 2.85-3.29; IgM: 4.07-4.95); $++=$ moderate titre (IgG: $3 \cdot 30-5 \cdot 05$; IgM: $4 \cdot 96-6 \cdot 00) ;+++=$ high titre (IgG: $\geqslant 5.06$; IgM: $\geqslant 6.01$ ).

Table 2: Sensitivity, specificity and predictive value of the IgG anticardiolipin antibody test for thrombosis and thrombocytopenia

\begin{tabular}{|c|c|c|c|c|c|c|}
\hline & \multicolumn{2}{|c|}{$\begin{array}{l}\text { Sensitivity } \\
(\%)\end{array}$} & \multicolumn{2}{|c|}{$\begin{array}{l}\text { Specificity } \\
(\%)\end{array}$} & \multicolumn{2}{|c|}{$\begin{array}{l}\text { Predictive value } \\
(\%)\end{array}$} \\
\hline & $A^{*}$ & $B^{*}$ & $A$ & $B$ & $A$ & $B$ \\
\hline $\begin{array}{l}\text { Low titre } \\
\text { Moderate titre } \\
\text { High titre }\end{array}$ & $\begin{array}{l}70 \\
50 \\
20\end{array}$ & $\begin{array}{l}47 \\
35 \\
18\end{array}$ & $\begin{array}{l}81 \\
89 \\
96\end{array}$ & $\begin{array}{l}81 \\
89 \\
96\end{array}$ & $\begin{array}{l}29 \\
33 \\
33\end{array}$ & $\begin{array}{l}33 \\
40 \\
50\end{array}$ \\
\hline
\end{tabular}

${ }^{*} \mathrm{~A}=$ thrombosis; $\mathrm{B}=$ thrombocytopenia.

the range $33-50 \%$. Interestingly when the binding index was $\geqslant 7.93$ the predictive values for thrombosis and thrombocytopenia were $67 \%$.

IgM ANTICARDIOLIPIN ANTIBODY ASSOCIATIONS In comparison with the 80 patients without IgM aCL, those with these antibodies had an increased incidence of haemolytic anaemia $(p=0.01)$ and neutropenia $(p=0.005)$. In addition, stepwise regression analysis of $\operatorname{IgM}$ anticardiolipin antibody titres with 16 variables showed significant correlations with haemolytic anaemia $(p=0.015)$ and neutropenia $(p=0.01)$.

Table 3 shows sensitivity, specificity, and predictive value of the IgM anticardiolipin antibody test at low, moderate, and high antibody titres for haemolytic anaemia and neutropenia. At moderate and high titres the specificity of the test for both variables exceeded $80 \%$, the sensitivity for haemolytic anaemia was $44 \%$ and for neutropenia $60 \%$. When the binding index was $\geqslant 11$ the predictive value for haemolytic anaemia was $60 \%$, and when the binding index was $\geqslant 15$ the predictive value was $100 \%$. In 
Table 3: Sensitivity, specificity and predictive value of the IgM anticardiolipin antibody test for haemolytic anaemia and neutropenia

\begin{tabular}{|c|c|c|c|c|c|c|}
\hline & \multicolumn{2}{|c|}{$\begin{array}{l}\text { Sensitivity } \\
(\%)\end{array}$} & \multicolumn{2}{|c|}{$\begin{array}{l}\text { Specificity } \\
(\%)\end{array}$} & \multicolumn{2}{|c|}{$\begin{array}{l}\text { Predictive value } \\
(\%)\end{array}$} \\
\hline & $A^{*}$ & $B^{*}$ & $A$ & $B$ & $A$ & $B$ \\
\hline $\begin{array}{l}\text { Low titre } \\
\text { Moderate titre } \\
\text { High titre }\end{array}$ & $\begin{array}{l}56 \\
44 \\
44\end{array}$ & $\begin{array}{l}80 \\
60 \\
60\end{array}$ & $\begin{array}{l}84 \\
88 \\
90\end{array}$ & $\begin{array}{l}83 \\
87 \\
89\end{array}$ & $\begin{array}{l}25 \\
27 \\
31\end{array}$ & $\begin{array}{l}20 \\
20 \\
23\end{array}$ \\
\hline
\end{tabular}

${ }^{*} \mathrm{~A}=$ haemolytic anaemia; $\mathrm{B}=$ neutropenia.

addition, when the binding index was $\geqslant 15$ the predictive value for neutropenia was $50 \%$.

\section{OTHER ASSOCIATIONS}

Lupus anticoagulant was detected in 30 patients, and significant association with thrombosis $(p=0.05)$ and thrombocytopenia $(p=0.001)$ was found. In addition, BFP-STS (rapid plasma reagin) was present in 17 cases and no clinical or biological correlation was found.

\section{Discussion}

The need to establish an anticardiolipin antibody titre for identification of patients with anticardiolipin antibody associated clinical features is of paramount importance. ${ }^{8}$ The results of this study indicate that control and SLE groups have a non-normal (log-normal) distribution of anticardiolipin antibody titres. To exclude the largest number of false positive anticardiolipin antibody sera only titres greater than $3.77 \mathrm{SD}$ (binding index $\geqslant 2.85$ ) were included for IgG aCL and greater than 3.90 SD (binding index $\geqslant 4 \cdot 07$ ) for IgM aCL.

The prevalence of $\mathrm{aCL}$ in our population with SLE is similar to that reported by other authors $^{10}{ }^{14}$ using an ELISA. IgG aCL were detected in $24 \%$ of an unselected group of patients, IgM aCL in $20 \%$, and either IgG or IgM aCL in $36 \%$. A much higher prevalence was found by Harris et al using radioimmunoassay. ${ }^{3}$ The differences in the reported prevalences of anticardiolipin antibody positivity may be due to differences in the sensitivity of the radioimmunoassay and ELISA techniques, in the cut off positive level, or may reflect the effects of patient selection and treatment.

The association of aPL (usually IgG aCL or lupus anticoagulant) with thrombosis, recurrent fetal loss, and thrombocytopenia has been reported in several studies. ${ }^{1-16}$ In general, these studies have determined the antiphospholipid antibody status of randomly selected patients with SLE and clinical and laboratory features recorded by review of their medical charts. In our prospective study we confirmed the previously reported association of IgG aCL with thrombosis and thrombocytopenia. The association with recurrent fetal loss, however, was not examined because no patient had an intrauterine death during the study. Nevertheless, analysis of 12 patients from this series with previous fetal losses (data not included) showed no association with the anticardiolipin antibody titre at the moment of the study. In our opinion the lack of such an association is not surprising.
Firstly, it may be due to the existence of a variable period of years between the fetal loss and the determination of the anticardiolipin antibody titre. Secondly, phospholipids other than cardiolipin may be related to the recurrent fetal loss. Thirdly, other antibodies such as antiRo or antilymphocyte may occasionally be involved in the pathogenesis of fetal losses. ${ }^{33}$

We found a significant association between the presence of IgM aCL and haemolytic anaemia and neutropenia. Although Coombs' positivity is common in patients with SLE who have $\mathrm{aCL},{ }^{3}$ the association with haemolytic anaemia has previously been recognised only by Delezé et $a l^{17}$ and Alarcón-Segovia. ${ }^{34}$ These authors consider that aPL may react with the cell wall of either erythrocytes or platelets and can cause their destruction either by complement or by receptor mediated entrapment by the reticuloendothelial system. Possibly, IgM aCL would best cause spleen clearance of erythrocytes and their complement mediated damage could hence be entertained. A similar mechanism would cause neutropenia.

No association between aCL and neurological events other than cerebrovascular accidents was found in our study. This lack of association may be due to the small number of patients (14 patients had migraine and two seizures). Nevertheless, both patients with cerebrovascular accidents had a positive anticardiolipin antibody titre.

Statistically significant association was found in our study between the presence of $\mathrm{aCL}$ and lupus anticoagulant, but not between $\mathrm{aCL}$ and BFP-STS. Similar results have been reported by other authors, ${ }^{35}$ and they may be due to differences in phospholipid epitope specificity. ${ }^{6}$

In conclusion, we observed a high incidence of $\mathrm{aCL}$ in our SLE population and showed a relation between $\mathrm{IgG} \mathrm{aCL}$ and thrombosis and thrombocytopenia and also between IgM aCL and haemolytic anaemia and neutropenia. Identification of these differences in the anticardiolipin antibody isotype associations may improve the clinical usefulness of these tests. In addition, the findings of this study confirm that the anticardiolipin antibody titre has a good predictive value for those clinical manifestations and may be a good predictor in patients with SLE. Supported by grants CAICYT PA $86-0016$ and FISS $88 / 1155$.
Ricard Cervera is a research fellow sponsored by a grant from the Ricard Cervera is a research fellow sponso
Hospital Clinic i Provincial of Barcelona.

1 Mueh J R, Herbst K D, Rapaport S I. Thrombosis in patients with the lupus anticoagulant. Ann Intern Med 1980; 92: 156-9.

2 Boey M L, Colaço C B, Gharavi A E, Elkon K B, Loizou S, Hughes G R V. Thrombosis in systemic lupus erythematosus: striking association with the presence of circulating lupus striking association with the presence of circu
anticoagulant. $\mathrm{Br} M$ Med $\mathrm{f} 1983 ; 287$ : 1021-3.

3 Harris E N, Gharavi A E, Boey M L, et al. Anticardiolipin antibodies: detection by radioimmunoassay and association with 1983; ii: $1211-4$.

Glueck H I, Kant K S, Weiss M A, Pollak V E, Miller M A Coots $M$. Thrombosis in systemic lupus erythematosus. Relation to the presence of circulating anticoagulants. Arch Relation to the presence of circulat
Interm Med 1985; 145: 1389-95.

5 Font J, Cervera R, Casals F J, et al. Estudio de la relación de los anticuerpos antifosfolipidos con los fenómenos trombótilos anticuerpos antifosfolipidos con los fenómenos trombóticos y la actividad clínica del lup

6 Colaço C B, Male D K. Anti-phospholipid antibodies in 
syphilis and a thrombotic subset of SLE: distinct profiles of epitope specificity. Clin Exp Immunol 1985; 59: 449-56.

7 Isenberg D A, Colaço C B, Dudeney C, Todd-Pokropek A Snaith M L. The relationship of anti-DNA antibody idiotypes and anticardiolipin antibodies to disease activity in idiotypes and anticardiolipin antibodies to disease activity in systemic lup 65 : $46-55$.

8 Harris E N, Chan J K H, Asherson R A, Aber V R, Gharavi A E, Hughes G R V. Thrombosis, recurrent fetal loss, and thrombocytopenia. Predictive value of the anticardiolipin antibody test. Arch Intern Med 1986; 146: 2153-6.

9 Ordi J, Vilardell M, Barquinero J, Selva A, Alijotas J, Bosch J. Fenómenos trombóticos y anticoagulante lúpico en una serie de 112 enfermos con lupus eritematoso sistémico. Rev Clin Esp 1987; 180: 66-70.

10 Petri M, Rheinschmidt M, Whiting-O'Keefe Q, Hellman D, Corash $\mathrm{L}$. The frequency of lupus anticoagulant in systemic lupus erythematosus. A study of sixty consecutive patients by activated partial thromboplastin time, Russell viper venom time, and anticardiolipin antibody level. Ann Intern Med 1987; 106: 524-31.

11 Derksen R H W M, Hasselaar P, Blokzijl L, Gmelig Meyling F H J, De Groot P G. Coagulation screen is more specific than the anticardiolipin antibody ELISA in defining thrombotic subset of lupus patients. Ann Rheum Dis 1988 47: 364-71.

12 Derue G, Englert H, Harris E N, et al. Fetal loss in systemic lupus: association with anticardiolipin antibodies. $\mathcal{f}$ Obstet Gynecol Neonatal Nurs 1985; 2: 207-9.

13 Lockshin M D, Druzin M L, Goei S, et al. Antibody to cardiolipin as a predictor of fetal distress or death in pregnant patients with systemic lupus erythematosus. $N$ pregnant patients with system.
Engl f Med 1985; 313: 152-6.

14 Fort J G, Cowchock F S, Abruzzo J L, Smith J B. Anticardiolipin antibodies in patients with rheumatic Anticardiolipin antibodies in patients

15 Cronin M E, Biswas R M, Van der Straeton C, Fleisher T A Klippel J H. IgG and IgM anticardiolipin antibodies in patients with lupus with anticardiolipin antibody associated clinical syndromes. F Rheumatol 1988; 15: 795-8.

16 Hazeltine M, Rauch J, Danoff D, Esdaile J M, Tannenbaum H. Antiphospholipid antibodies in systemic lupus erythematosus: evidence of an association with positive Coombs' and hypocomplementemia. F Rheumatol 1988; 15: 80-6.

17 Delezé M, Alarcón-Segovia D, Oria C V. Occurrence of both hemolytic ancmis and hemolycic anconic and syndrome) in systemic lupus erythematosus. Relationship to 18 Asherson R A, Mercey D, Phillips G, et al. Recurrent stroke and multi-infarct dementia in systemic lupus erythematosus: association with antiphospholipid antibodies. Ann Rheum Dis 1987; 46: 605-11.

19 Asherson R A, Harris E N. Anticardiolipin antibodies. Clinical associations. Postgrad Med $\mathcal{J}$ 1986; 62: 1081-7.
20 Khamashta M A, Gil A, Anciones B, et al. Chorea in systemic lupus erythematosus: association with antiphospholipid antibodies. Ann Rheum Dis 1988; 47: 681-3.

21 Manoussakis M N Gharavi A E Drosos A A, Kitridou R C, Moutsopoulos $\mathrm{H} M$. Anticardiolipin antibodies in unselected autoimmune rheumatic disease patients. Clin Immunol autoimmune rheumatic disease

22 Sturfelt G Nived O, Norberg R, Thorstensson R, Krook $K$ Anticardiolipin antibodies in patients with systemic lupus 30: 382-8

23 Petri M, Golbus M, Anderson R, Whiting-O'Keefe Q, Corash L, Hellmann D. Antinuclear antibody, lupus anticoagulant, and anticardiolipin antibody in women with idiopathic habitual abortion. Arthritis Rheum 1987; 30 601-6.

24 Loizou S, McCrea J D, Rudge A C, Reynolds R, Boyle C C, Harris E N. Measurement of anticardiolipin antibodies by an enzyme-linked immunosorbent assay (ELISA): standardization and quantization of results. Clin Exp Immunol 1985; 62: 738-45.

25 Tan E M, Cohen A S, Fries J, et al. The 1982 revised criteria for classification of SLE. Arthritis Rheum 1982; 25: 1271-2.

26 American Retion of SLE. Arhritis Rheum 1982,25 . $1271-2$. and symptoms. Dictionary of the Rheumatic Disease 1982; 1 : $1-80$.

27 Gharavi A E, Harris E N, Asherson R A, Hughes G R V. Anticardiolipin antibodies: isotype distribution and phospholipid specificity. Ann Rheum Dis 1987; 46: 1-6.

28 Thiagarajan $\mathrm{P}$, Shapiro S S. Lupus anticoagulants. In Colman R V, ed. Methods in hematology: disorders of thrombin formation other than hemophilia. New York: Livingstone, 1983: 101-3.

29 Green D, Hougie C, Kazmier F J, et al. Report of the working party on acquired inhibitors of coagulation: studies of the 'lupus' anticoagulant. Thromb Haemost 1983; 49: of the

30 Wold R T, Young F E, Tan E M, Farr E R S. Deoxyribonucleic acid antibody: a method to detect its primary interaction with deoxyribonucleic acid. Science 1968; 161: 806-7.

31 Lachmann P J, Hobart M J. Complement technology. Handbook of experimental immunology. Vol 1. London: Blackwell Scientific, 1978

32 Galen R S, Gambino R S. Beyond normality: the predictive value and efficiency of medical diagnoses. New York: Wiley, 1975

33 Scott J R, Rote N S, Branch D W. Immunologic aspects of recurrent abortion and fetal death. Obstet Gynecol 1987; 70: 645-55.

34 Alarcón-Segovia D. Pathogenetic potential of antiphospholipid antibodies. F Rheumatol 1988; 15: 890-3.

35 Weidmann C E, Wallace D J, Peter J B, et al. Studies of IgG, IgM and IgA anticardiolipin antibody isotypes in systemic lupus erythematosus. $\mathcal{F}$ Rheumatol 1988; 15: 74-9. 